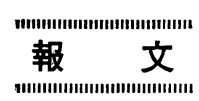

\title{
鋼製水槽およひ温水器内面防錆塗料の性能試験
}

\author{
後藤田正夫* 関口吉 造*

\section{Tests on Corrosion-Resistant Paints for Use on the Interior of Steel Water Tanks and Water Heaters}

\author{
Masao Gotôda and Kichizô Sekiguchi
}

The present experiment has been executed with the purpose to choose a paint with high corrosion-resistance and durability which is suitable for repainting the interior of the water reservoir and the water heater made of steel plate which are provided on passenger cars.

In the first report, some 30 commercial brands for the above-mentioned use were tested for their general properties, their durability under ac-

\section{1. 緒言}

真水貯水タンクは普通軟鋼板製のものが多く，一般に 防錆処理を施して使用される。外面は錆止塗料および耐 候性叙料を塗装することによって，かなり長期の耐久性 が得られるが, 内面は常時真水や水蒸気に接して発錆し 易い状態にさらされているので，防錆処理剂および処理 オj法には難点が多い。現在ではメタリコン, 電気防食, 塗装およびこれらの併用など行なわれているが，それぞ れ一長一短がある。ことに古いタンクの再防錆処理に は, 古い塗膜, 点錆など十分なる除去をして再塗装しな ければならない。

現在国鉄で客車に備えている床下水槽（約 $700 l$ 入り） および温水器 (約 $200 l$ 入り, 温度 $40 \sim 60^{\circ} \mathrm{C}$ ) は新車 の軽合金製のものを除いて，従来のものは鋼板 製であ り, 再三塗り替えて使用されている。従ってここに用い る塗料は長期にわたり耐水性, 防食性の良いものが望ま れる。筆者らはかかる水タンクおよび温水器内部の防錆 を目的とし，耐久性の良い塗料を見出す目的で昭和 33 年から 35 年にかけて本試験を行なったのでその結果を 報告する。

このような水槽内面塗装として,たとえば Keane ら1) は大型鋼製貯水槽内面塗装に対する各種塗料の長期（約 8 年) 浸漬試験の結果, ビニル塗料が良好なことおよび 望装前処理は大差を生じないことを見出している。また Christofferson') は従来の鉛丹-アマニ油塗料がすぐれ ているが, 毒性の点から問題があるとし, その他の各種

\footnotetext{
* 鉄道技術研究所 (東京都北多摩郡国分寺町)
}

celerated deterioration under passage of current, and long time immersion in distilled water and several of them for their durability under immersion in tepid to hot water in the water heater. The results show that coal-tar enamel, PVC or epoxy paints are relatively effective for painting the water reservoir; and epoxy enamel, PVC or saran paints have practical effect in the interior of the water heater.

塗料の優劣を論じている。

ところでこのような塗料を比較する場合, 同一整料で も組成を少しく変えることにより, 性能が著しく変化す ることが間々あるので, 市販塗料をそのまま比較した本 実験のごとき結果から, 直ちにその采統の塗料が不良で あるとの結論を出すことは危険と思われる。

たと光ば Moroson ${ }^{3)}$ はエポキシ塗料が，その硬化戍 の種類により, 淡水中の耐久性およびふくれの発生難易 に差があることを報告している。

\section{2. 試 験 方 法}

現行客車水タンクおよび温水器内部は, 新規取り付け 後これまでに再三塗り替えを行ない, 素地面にかなりの 凹凸ができており，塗り替えのつどサンドブラスト，ス クレーパーなどで旧塗膜および錆を磨き落す際，凹部な ぞにわずかであるが塗膜や錆が残留し易い。このような 面へ再塗装（主に刷毛塗り）を行なうのであるから, 塗 膜の密着性, 厚さの不均一などの問題が生じ易く, 塗膜 の耐久性は新しい素地面へ塗装する場合より劣るのが一 般である。

そこで本試験では, まず供試塗料として従来の経験か ら防錆力, 耐水性, 密着性および作業性等が良いと思わ れてきているものを市販品から選えだ。また被塗装鋼板 は, 素地面が現場のものと同程度に腐食したものが得に くく, かつ塗料の性能比較を行なうためには, むしろ均 一によく磨いた新試験片を使用した方が良いと考え, 良 く磨いた軟鋼板を用いることとした。

次に各塗料について塗装試験片を作製し, 塗料の作業 
表 1 水タンク内部

\begin{tabular}{|c|c|c|c|c|c|c|c|c|c|c|}
\hline \multirow{2}{*}{ 㳂 料 系 } & \multirow{2}{*}{ 型 } & \multirow{2}{*}{ No. } & \multirow{2}{*}{ 谽回数 } & \multirow{2}{*}{$\begin{array}{l}\text { 作＼cjkstart業＼cjkstart性 } \\
\text { （はけさばき） }\end{array}$} & \multirow{2}{*}{$\begin{array}{l}\text { 膜 厚 } \\
\mathrm{mm}\end{array}$} & \multirow{2}{*}{$\begin{array}{l}\text { 仕上り } \\
\text { 色 }\end{array}$} & \multirow{2}{*}{$\begin{array}{l}\text { 密着性 } \\
\text { （描画） }\end{array}$} & \multirow{2}{*}{ 耐塩水試験 } & \multicolumn{2}{|c|}{ 通電劣化試駧 } \\
\hline & & & & & & & & & 通電流 & 趴＼cjkstart膜 \\
\hline ジンクリッチベイント & 亜 & $\begin{array}{l}1 \\
2 \\
3 \\
4 \\
5 \\
6\end{array}$ & $\begin{array}{l}2 \\
4 \\
2 \\
2 \\
3 \\
2\end{array}$ & 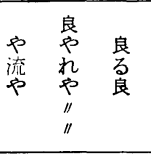 & $\begin{array}{r}0.07 \\
9 \\
6 \\
7 \\
11 \\
15\end{array}$ & $\begin{array}{l}\text { 灰 } \\
\text { " } \\
\text { " } \\
\text { " } \\
\text { " }\end{array}$ & & 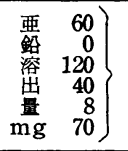 & $\begin{array}{l}\text { 通電試験 } \\
\text { 永, 别に } \\
\text { 水試験を }\end{array}$ & $\begin{array}{l}\text { は行なわ } \\
7 \text { 日間耐塲 } \\
\text { 続けた結果 }\end{array}$ \\
\hline 性 & 亜 酸 化 鉊 & $\begin{array}{l}7 \\
8 \\
\end{array}$ & $\begin{array}{l}4 \\
4 \\
\end{array}$ & $\begin{array}{l}\text { 良 } \\
\text { " }\end{array}$ & $\begin{array}{l}16 \\
18 \\
\end{array}$ & ね銀み & $\begin{array}{l}\text { 不良 } \\
\text { pや良 }\end{array}$ & 合 ”格 & $\begin{array}{l}0 \\
0\end{array}$ & 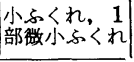 \\
\hline \multirow{2}{*}{$100 \%>=1-\pi$} & 恶＼cjkstart鉊 & 9 & 3 & 良 & 8 & $" 1$ & 不 良 & 不 合 格 & \multicolumn{2}{|c|}{ 数力所, 特に水面部に } \\
\hline & シ アル゙ミド 鉛 & $\begin{array}{l}10 \\
11\end{array}$ & $\begin{array}{l}3 \\
4 \\
\end{array}$ & や ” 良 & $\begin{array}{l}15 \\
24\end{array}$ & ね泉み & 不良良 & 合 & $\begin{array}{l}0 \\
0\end{array}$ & 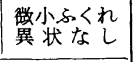 \\
\hline 塩 化 $ヒ=N$ & (染りク & $\begin{array}{l}12 \\
13 \\
14 \\
15 \\
\end{array}$ & $\begin{array}{l}6 \\
5 \\
7 \\
5\end{array}$ & $\begin{array}{l}\text { 良 } \\
" 1 \\
\text { " } \\
\text { " }\end{array}$ & $\begin{array}{l}16 \\
13 \\
16 \\
10\end{array}$ & $\begin{array}{l}\text { 白 } \\
\text { " } \\
\text { 銀 }\end{array}$ & $\begin{array}{l}\text { やや良 } \\
\text { 不や良 } \\
\text { 良 }\end{array}$ & 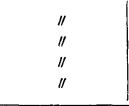 & $\begin{array}{l}0 \\
0 \\
0 \\
0 \\
\end{array}$ & $\begin{array}{l}\text { " } \\
\text { "I } \\
\text { " }\end{array}$ \\
\hline 塩化 ビ = リ デン & " & 16 & 8 & 良 & 13 & 銀 & やや良 & " & 0 & " \\
\hline エ ポ & 酸 & $\begin{array}{l}17 \\
18 \\
19\end{array}$ & $\begin{array}{l}4 \\
2 \\
4\end{array}$ & $\begin{array}{c}\text { 調 合泩 意 } \\
\text { 良 } \\
\end{array}$ & $\begin{array}{r}16 \\
8 \\
12\end{array}$ & $\begin{array}{l}\text { 白 } \\
\text { " } \\
" 1\end{array}$ & 不良 & "I & $\begin{array}{l}0 \\
0 \\
0\end{array}$ & 兾状なし \\
\hline ボリエステル十エポキシ & 化 & 20 & 3 & 調 合 注 意 & 19 & ねずみ & 不 良 & $"$ & 0 & $"$ \\
\hline + $\quad$ ラ & - & 21 & 3 & 良 & 15 & 白 & " & " & 0 & $"$ \\
\hline ボリウレタン & (ジンクロプライマー) & $\begin{array}{l}22 \\
23\end{array}$ & $\begin{array}{l}\mathbf{5} \\
\mathbf{3}\end{array}$ & 調 合 注 意 & $\begin{array}{l}13 \\
20\end{array}$ & 白 & " & " & $\begin{array}{l}0 \\
0\end{array}$ & " \\
\hline $\bar{F}$ & $=$ & $\begin{array}{l}24 \\
25\end{array}$ & $\begin{array}{l}3 \\
1\end{array}$ & 短ィニン姇 & $\begin{array}{l}20 \\
40\end{array}$ & 茶 褐 & や”良 & " & $\begin{array}{l}0 \\
0\end{array}$ & $\begin{array}{l}\text { ふくれ数十 } \\
\text { 異状しし }\end{array}$ \\
\hline ニールタールエナメル & 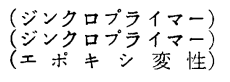 & $\begin{array}{l}26 \\
27 \\
28\end{array}$ & $\begin{array}{l}4 \\
2 \\
3\end{array}$ & 溶 $\begin{array}{ll}\text { 良 } \\
\text { 良 }\end{array}$ & $\begin{array}{r}55 \\
2.00 \\
45\end{array}$ & $\begin{array}{l}\text { 黒 } \\
\text { "I } \\
\text { "I }\end{array}$ & 不良 & "I" & $\begin{array}{l}0 \\
0 \\
0\end{array}$ & " \\
\hline 㱘 & - & 29 & 3 & 良 & 12 & 黒 & 良 & $"$ & $\begin{array}{l}36 \text { 日目 } \\
90 \mu \mathrm{A}\end{array} \mid$ & 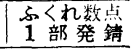 \\
\hline
\end{tabular}

性，膜厚，密着性をそれぞれ調査し，次いで耐塩水試

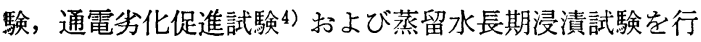
ない，また温水器用の塗料については，熱湯および温湯 浸漬試験を行ない，塗膜の劣化状況を調査し，各々につ いて耐久性を比較検討した。

\section{3. 試 験 結 果}

試験板には冷間圧延軟鋼板 $(150 \times 50 \times 1 \mathrm{~mm})$ を用い, 研摩紙 \#100，\#240でよく磨き，四塩化エチンンで十 分脱脂後乾燥して, 各塗料を所定の塗装基準により刷毛 塗りし, 温度 $20^{\circ} \mathrm{C}$, 湿度 $70 \%$ の恒温室で 1 週間乾燥 して試験に供した。

約 30 点の供試塗料は，ビヒクルの成分に基づき分類 すれば，ジンクリッチペイント，油性系，100\%フェノ ール系, 塩化ビニル系, 塩化ビニリデン系, エポキシ 系, ポリエステル十エポキシ系, サラン系, ポリウレタ ン系, フラン系, コールタールエナメルおよび源青系の 12 塗料系となる。更に各系はピグメントの種類により 数種の型に分類し得る (表 1 参照)。

これらの塗料につき以下の諸点について試験検討を行 なった。

\section{1) 作 業 性}

刷毛塗りによる「はけさばき」の難易, 塗料調合の手 間，調合後の使用制限時間（いわゆるポットライフ）の 有無, 長短, 乾燥時間等, 主として定性的ではあるが, 総合的に作業性を判定した。

作業性のよいものは油性系, フェノール系, 塭化ビニ ル系, 溶液型コールタールエナメル等で, 新しい合成樹 脂系塗料の中には乾燥速度が速く, 従って「はけさば き」が不良のもの，また調合後速に硬化するもの，ある いは可使用時間を制限されるものがあって，作業性がや や困難なものが多い。またライニング塗料は流し塗りか 漬け塗り，あるいは溶融コールタールペイントと同椂作 業性に難点が多い。ジンクリッチペイントの中には, 流 れを生じたり，重社塗りを行なうと下地を再溶解するも のなどがある。

塗料溶剤（シンナー）に注覀臭, 刺激性, 有毒性およ び引火性のあるものがあり，これは主に合成樹脂系塗料 溶剤に多く，作業中には換気，火気に注意を要する。

\section{2) 症回数, 膜厚}

塩化ビニル系, ポリウレタン系およびュールタール系 は下塗りにジンクロプライマーを施し, 3〜4 回塗り仕 上げするものが多いが，塭化ビニル系の一部には $5 \sim 7$ 
防食塗料試験結果

\begin{tabular}{|c|c|c|c|c|c|c|c|c|c|c|c|c|}
\hline \multirow{3}{*}{$\begin{array}{c}1 \\
\mathrm{k} \Omega\end{array}$} & \multirow{3}{*}{$\frac{\text { 日 }}{\mu \mathrm{F}}$} & \multicolumn{2}{|c|}{ 蒸 } & \multirow{2}{*}{\multicolumn{2}{|c|}{$\frac{{ }^{*} \text { 留 }}{3 \text { 力月 }}$}} & \multirow{3}{*}{$\begin{array}{l}\text { 長 期 浸 } \\
\text { 膜 異 状 }\end{array}$} & \multirow{2}{*}{\multicolumn{2}{|c|}{$\frac{\text { 漬 }}{\text { 試 }}$}} & \multirow{3}{*}{$\begin{array}{ll}\text { 験 } & \mathrm{k} \Omega \cdots \text { 膜抵坑 } \\
& \text { 膜 } \\
\text { 異 }\end{array}$} & \multicolumn{3}{|c|}{$\mu \mathrm{F} \cdots$ 電気容量 } \\
\hline & & \multicolumn{2}{|c|}{1 力月 } & & & & & & & \multicolumn{2}{|c|}{1 力年 } & \multirow{2}{*}{ 膜 } \\
\hline & & $\mathrm{k} \Omega$ & $\mu \mathrm{F}$ & \multicolumn{2}{|c|}{\begin{tabular}{|l|l|}
$\mathrm{k} \Omega$ & $\mu \mathrm{F}$
\end{tabular}} & & \multicolumn{2}{|c|}{\begin{tabular}{l|l}
$\mathrm{k} \Omega$ & $\mu \mathrm{F}$ \\
\end{tabular}} & & $\mathrm{k} \Omega$ & $\mu \mathrm{F}$ & \\
\hline \multicolumn{13}{|c|}{ 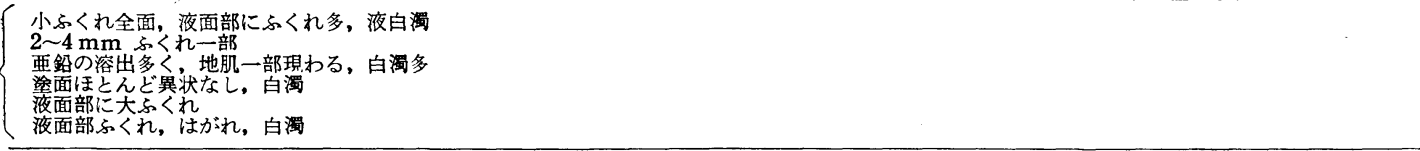 } \\
\hline \multicolumn{2}{|c|}{\begin{tabular}{r|r|}
65 & 0.0041 \\
70 & 38 \\
\end{tabular}} & \multicolumn{2}{|c|}{\begin{tabular}{r|r|}
60 & 0.0019 \\
54 & 20 \\
\end{tabular}} & \multicolumn{2}{|c|}{\begin{tabular}{|r|r|}
47 & 0.0027 \\
44 & 28 \\
\end{tabular}} & & \multicolumn{2}{|c|}{\begin{tabular}{|r|r|}
42 & 0.0025 \\
33 & 32 \\
\end{tabular}} & 铛 小 & \multicolumn{2}{|c|}{\begin{tabular}{|r|r|}
32 & 0.0029 \\
28 & 26 \\
\end{tabular}} & $\begin{array}{l}1 \text { 点錆 } 2 \mathrm{~mm} \text { 市くれ全面 } \\
2 \sim 3 \mathrm{~mm} \text { ふく全面 }\end{array}$ \\
\hline \multicolumn{13}{|c|}{ ふくれ，10 日間浸漬では錆数点発生 } \\
\hline $\begin{array}{l}185 \\
355\end{array}$ & $\begin{array}{l}25 \\
19\end{array}$ & $\begin{array}{r}61 \\
148\end{array}$ & $\begin{array}{l}17 \\
15\end{array}$ & $\begin{array}{l}114 \\
166\end{array}$ & $\begin{array}{l}24 \\
21\end{array}$ & & $\begin{array}{l}133 \\
182\end{array}$ & $\begin{array}{l}29 \\
25\end{array}$ & 京 $2 \mathrm{~mm}$ s $<$ れ & $\begin{array}{r}86 \\
115\end{array}$ & $\begin{array}{l}28 \\
23\end{array}$ & $1 \mathrm{~mm}$ 衣 以下等首 \\
\hline $\begin{array}{r}112 \\
83 \\
96 \\
103 \\
\end{array}$ & $\begin{array}{l}20 \\
23 \\
22 \\
22\end{array}$ & $\begin{array}{r}107 \\
77 \\
104 \\
123\end{array}$ & $\begin{array}{l}24 \\
27 \\
25 \\
24\end{array}$ & $\begin{array}{r}118 \\
81 \\
130 \\
148\end{array}$ & $\begin{array}{l}28 \\
32 \\
28 \\
27\end{array}$ & $\begin{array}{l}1 \sim 2 \mathrm{~mm} \text { ふ }<~ \\
\text { ふ }<\text { れ }\end{array}$ & $\begin{array}{r}111 \\
87 \\
138 \\
150\end{array}$ & $\begin{array}{l}19 \\
25 \\
20 \\
23\end{array}$ & $<$ れ 小 & $\begin{array}{r}105 \\
83 \\
130 \\
170\end{array}$ & $\begin{array}{l}23 \\
26 \\
24 \\
22\end{array}$ & 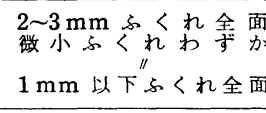 \\
\hline 50 & 25 & 52 & 31 & 50 & 38 & 下部に小ふくれ多 & 61 & 30 & 下部にふくれ & 70 & 28 & 小 $<れ$ 周 辺 \\
\hline $\begin{array}{l}84 \\
96 \\
96\end{array}$ & $\begin{array}{l}22 \\
22 \\
23\end{array}$ & $\begin{array}{r}68 \\
101 \\
117\end{array}$ & $\begin{array}{l}29 \\
28 \\
26\end{array}$ & $\begin{array}{l}127 \\
128 \\
160\end{array}$ & $\begin{array}{l}28 \\
31 \\
29\end{array}$ & ざずがさら肌 & $\begin{array}{l}108 \\
166 \\
225\end{array}$ & $\begin{array}{l}27 \\
28 \\
26\end{array}$ & 光 沢 失 j & $\begin{array}{r}53 \\
131 \\
164\end{array}$ & $\begin{array}{l}34 \\
28 \\
27\end{array}$ & 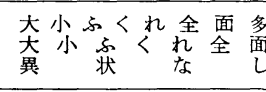 \\
\hline 48 & 34 & 52 & 20 & 51 & 30 & & 50 & 52 & & 37 & $27 \mid$ & $2 \sim 4 \mathrm{~mm}$ s $<$ 全面 \\
\hline $\begin{array}{r}65 \\
220\end{array}$ & $\begin{array}{r}39 \\
23\end{array}$ & $\begin{array}{r}50 \\
111\end{array}$ & $\begin{array}{l}36 \\
20\end{array}$ & $\begin{array}{r}55 \\
121\end{array}$ & $\begin{array}{r}23 \\
24\end{array}$ & 小 $く<れ$ & $\begin{array}{r}64 \\
254\end{array}$ & $\begin{array}{l}17 \\
26\end{array}$ & 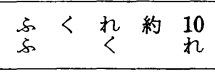 & $\begin{array}{r}34 \\
140 \\
\end{array}$ & $\begin{array}{l}39 \\
24\end{array}$ & 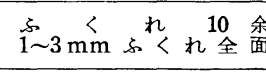 \\
\hline $\begin{array}{l}125 \\
575\end{array}$ & $\begin{array}{l}28 \\
01\end{array}$ & $\begin{array}{r}135 \\
402\end{array}$ & $\begin{array}{l}28 \\
11\end{array}$ & $\begin{array}{r}110 \\
490\end{array}$ & $\begin{array}{l}23 \\
12\end{array}$ & $1 \sim 2 \mathrm{~mm}$ s $<れ$ & $\begin{array}{l}110 \\
650\end{array}$ & $\begin{array}{l}18 \\
12\end{array}$ & 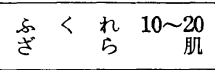 & $\begin{array}{l}115 \\
305\end{array}$ & $\begin{array}{l}30 \\
14\end{array}$ & 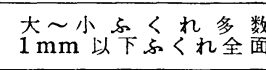 \\
\hline $\begin{array}{l}2,100 \\
4,600 \\
1,600\end{array}$ & $\begin{array}{l}47 \\
25 \\
64\end{array}$ & $\mid \begin{array}{l}1,850 \\
2,400 \\
1,500\end{array}$ & $\begin{array}{l}05 \\
02 \\
07\end{array}$ & $\mid \begin{array}{l}1,400 \\
7,300 \\
1,230\end{array}$ & $\begin{array}{l}05 \\
02 \\
07\end{array}$ & & $\begin{array}{r}1,150 \\
5,000 \\
900\end{array}$ & $\begin{array}{l}05 \\
02 \\
06\end{array}$ & & $\left|\begin{array}{l}1,700 \\
9,000 \\
2,100\end{array}\right|$ & $\begin{array}{l}05 \\
02 \\
07\end{array}$ & 異状 \\
\hline 1,750 & 09 & 730 & 09 & 1,000 & 09 & & $|1,700|$ & 09 & & 1,130 & 09 & 徽 小心くれ全面 \\
\hline
\end{tabular}

回塗りを要する不便なものがある。樹脂ライニング，溶 融コールタールエナメルは，多くは 1 回塗りであるが， 塗装に熟練を要し，施行に難点がある。

膜厚は，ジンクリッチペイントについてはマイクロメ 一ターで，その他はエルュメーターで測定した。全般に 膜厚は $0.1 \mathrm{~mm}$ 前後のものが多い。ライニング塗料, コールタールエナメルなどは $1 \mathrm{~mm}$ 以上, 数 $\mathrm{mm}$ の厚 さのものもあり, かつ一様の厚さに施工することに困難 を感じた。

\section{3) 密 菁 性}

描画試験により判定した。塗膜が軟く，粘着性のある ものは, 油性系, コールタール系のごとく密着性がよい が塗膜が軟弱な欠点がある。これに反しエポキシ系のご とく硬い塗膜は描画のため，大荷重を掛けた場合，涂離 乙始めるとパラパラと㔀離し, 密着性が劣るように思わ れる。

\section{4) 耐塩水試験}

$\mathrm{JIS}$ 塗料規格に基づき， $5 \%$ 食塩水中に $20^{\circ} \mathrm{C}$ で 4 日 間塗装試験片を浸漬した結果では，ジンクリッチペイン トでは，大部分が $\mathrm{Zn}$ の溶出 $\left(100 \mathrm{~cm}^{2}\right.$ の塗装面から多 いもので $200 \mathrm{mg}$, 少ないもので $13 \mathrm{mg}$ )を認めた。溶
出量の多いものでは, 鉄素地面の露出した部分を認め た。しかし発錆はいずれも見受けられない。これは Zn が電気的に Fe の防食に関与し，かつ溶出した Znの一 部が水に溶出して，弱フルカリ性となることの影響によ るものと考えられる。溶出した $\mathrm{Zn}$ の大部分は $\mathrm{Zn}(\mathrm{OH})_{2}$ となり液中に白濁浮遊し，一部は沈殿している。このよ うな点から水タンクからの洗面水が白濁し，微フルカリ 性を呈する可能性があり，これは実用上好ましくないも のと思われる。

ジンクリッチペイントの上塗りにクリヤー塗料を施し て Zn の溶出を押えたものは，一部に小ふくれの発生を 見た。塩水浸漬を更に 7 日間続けた結果， $\mathrm{Zn}$ の溶出は 更に進行し一部にらくれを生じた。しかし当初から Zn の溶出の少ないものは，次第に溶出を認めなくなり，比 較的長期防食性を示すものと思われる。

ジンクリッチペイント以外の塗料については, フェノ ール系 1 点が数個所に点錆を発生したものを除き, 全部 本試験では異常を見せなかった。

\section{5) 通電劣化促進試験}

一般に塗装鋼板がすぐれた防食性を持つためには，塗 膜の密着性がよく，電気抵抗が大きく，かつ均一である 
こと, 従って膜厚も平均していることが望ましい。更に 耐水性塗料に打いては吸水性の少ないらとも必要であ る。

そこで鋈膜を透して通電し，このような塗膜の強制劣 化促進を行なう方法が従来から考えられている。ここで は日根ら ${ }^{4)}$ の方法により, その際の流電量と, 肉眼観察 による塗膜の異状を調べ, 劣化の程度を比較検討する方
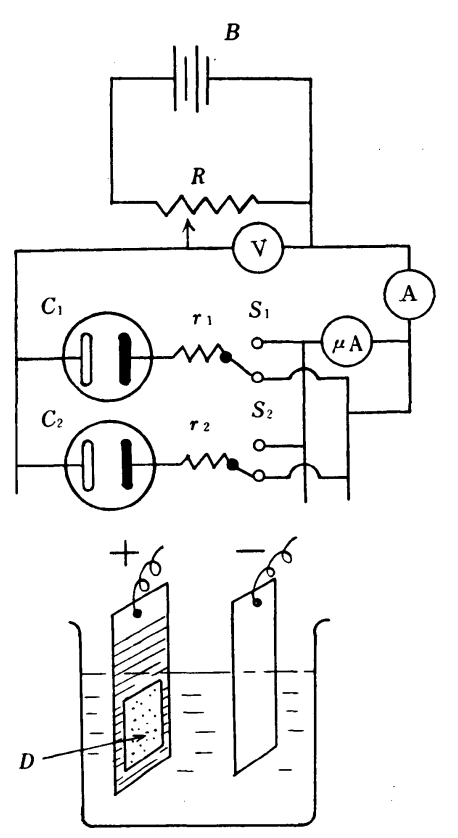

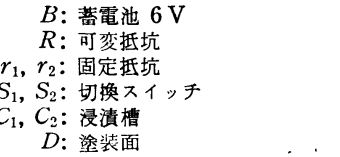

図 1 通電劣化促進装置 法を取った。そ れには図1のご とく叙装試験の 片面 $24 \mathrm{~cm}^{2}$ の 塗装面を残し， 周辺および裏面 をギルソナイト とブロンアスフ フルトの混合物 でシールして電 気的に絶縁し， $3 \%$ 食塩水に浸 漬し，これを陽 極とし, カーボ ン陰極を対極さ せ, 高抵抗 $(10$ $\mathrm{k} \Omega$ ) を直列飞 接続し, 直流 1 $\mathrm{V}$ の電圧を加 之連続 50 日間 室温で通電劣北 促進試験を行な った。流電量は 時々マイクロフ ンメーターで測定した。

本試験では瀝青系 1 点のみが 36 日で流電量が $90 \mu \mathrm{A}$ に達し，かつ錆の発生が認められたのみで，その他では 電気的破壊は認められなかった。しかし長期の食塩水浸 漬の結果, 吸水による塗面のふくれを生じたものは数点 あった。

この試験では劣化がほとんど促進されなかったようで あるが，これは塗膜が 3 7 回叙りで比較的厚く, 最初 から電気抵抗が大で，耐水性がよかったためだと思われ る。従って，かかる試験では 1 2 回塗りの膜厚小な叙 装試験片について行なえば，比較的速く塗料の良否が判 定するものと考元られる。なおジンクリッチペイントに ついては本試験は行なわなかった。

\section{6) 蒸留水長期浸淩試験}

塗装試験片を蒸留水に浸漬すると, 叙装面から塗料中 の可溶分がイオンになって水中へ溶出して行くことが考
えられる。この量はきわめてわずかであるが, 水の純度 が高いほど溶出する速度が早く, 溶出量も多いはずであ る。これと同時に水の純度が高いほど，淩透圧による水 の塗膜への浸入が著しいことも考光られる。

これらの理由から筆者らは, ビーカーに蒸留水を満し た中へ, 塗装面 $48 \mathrm{~cm}^{2}$ を残して周囲をギルソナイトと ブロンアスファルトの混和物でシールした試験片を各 1 枚ずつ浸漬し, 室温に放置し, 蒸留水は時々各々につい てその比抵抗を測り, 純度の低下したものは新しい蒸留 水と取り替えて長期の浸漬試験を行なった。蒸留水はた と光ば初め $20 \mathrm{k} \Omega / \mathrm{cm}^{3}$ のものが一応 $10 \mathrm{k} \Omega / \mathrm{cm}^{3}$ に低 下すると，直ちに取り替えた。これは大体 10〜15 日間 隔となった。全般に浸漬した蒸留水中への溶出量増加に よる純度の低下は各塗料ともほとんど同程度であった。 しかし試験片中ライニング塗料の 1 点のみは蒸留水の比. 抵抗が短時日に抵下し，その低下速度は他の塗料に比べ て大体 3 倍程度であった。このことは温湯に浸漬した場 合でも認められ，このライニング荃料では浸漬温湯が急 速に茶褐色に着色した。

次に叙装試験片については，一定時間ごとにこれを取 り出し, 別に用意した蒸留水中で塗膜の交流抵抗と電気 容量を測定し, 同時に肉眼観察によりその劣化状況を調 べた。

これには岡本，諸住ら5)の方法に準拠し，浸漬液には 蒸留水を用いて行なっ た。そしてこれには図 2 のごとく, 塗装試験片は $500 \mathrm{cc}$ のビーカーに蒸留 水を満した中へ浸漬し て，無塗装の同一面積の 鋼板を対極とし，極間距 離 $30 \mathrm{~mm}$, 水温 $25^{\circ} \mathrm{C}$, 周波数 $1,000 \mathrm{c} / \mathrm{s}$ の交 流電橋により, 蒸留水中 の電気抵抗と容量を測定 した。測定值は上記の条 件での值で浸漬蒸留水の 抵抗値をむ含めている。 従って浸漬にたとえば食 塩水を用いた場合と異な

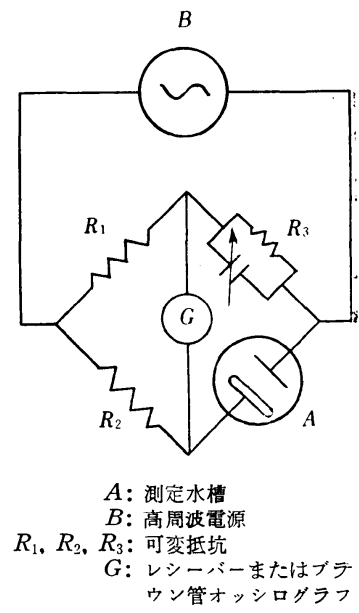

図 2 インピーダンス測 定装置 ってくる点に注意されたい。

交流抵抗值は約 $50 \mathrm{k} \Omega \sim 500 \mathrm{k} \Omega$ のものが多く、コー ルタールエナメルでは数 $1,000 \mathrm{k} \Omega$ であった。また電気 容量は 0.0001 0.005 $\mu \mathrm{F}$ であった。こ机らの值は試験 開始初期に, 前者ではわずかに低下し, 後者ではわずか に大となる傾向があるが数日後からはほとんど变化はな かった。そして1カ年の試験では，まだ塗膜は電気化学 
的に健全であることがわかった（一般に吸水，ピンホー ル，発錆などにより塗膜が劣化すると，抵抗は低下をき たし，容量は増大する)。

しかし他方肉眼観察では塗膜の異状が認められた。す なわち, 浸漬 3 力月頃からふくれを生じたものが現わ
れ，6 月月で約半数 (主に油性系, フェノール系, ポリ ウレタン系, 樹脂ライニング等) 1 力年で大多数のもの がふくれを生じた。全く異状を認めないものは，エポキ シ系 1 点, コールタールエナメル 3 点のみであった。か ように多くの塗膜にふくれの発生を認めたが，錆（油性

表 2 温水器用涂料の温, 熱湯浸漬試験結果

\begin{tabular}{|c|c|c|c|c|c|c|c|c|c|c|}
\hline \multirow{2}{*}{ 释 料 系 } & \multirow[t]{2}{*}{ 型 } & \multirow{2}{*}{ No. } & \multirow{2}{*}{ 塗回数 } & \multirow{2}{*}{ 作業性 } & \multirow{2}{*}{$\begin{array}{c}\text { 膜 厚 } \\
\mathrm{mm}\end{array}$} & \multirow{2}{*}{ 仕上り } & \multirow{2}{*}{$\begin{array}{l}\text { 耐塩水 } \\
\text { 試 験 }\end{array}$} & \multicolumn{2}{|c|}{$\begin{array}{ccc}\text { 温 } & \text { 湯 } & \begin{array}{c}\text { 浸漬 } \\
60^{\circ}\end{array} \text { 試 験 } \\
\end{array}$} & \multirow{2}{*}{$\begin{array}{c}\text { 熱湯浸清試験 } \\
\text { 微 沸 騰 䦪 } \\
\text { (〜25日間) }\end{array}$} \\
\hline & & & & & & & & 10 日間 & 50 日間 & \\
\hline \multirow{6}{*}{$\begin{array}{l}\text { ジンクリッチ } \\
\text { ベイント }\end{array}$} & \multirow{6}{*}{ 亜 鉊 末 } & 1 & - & - & - & - & - & - & - & 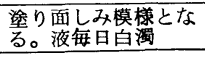 \\
\hline & & 2 & - & - & - & - & - & - & - & むろいふくれ \\
\hline & & 3 & - & - & - & - & - & - & - & $\begin{array}{l}\text { しみ模様となる，白 } \\
\text { 蜀 }\end{array}$ \\
\hline & & 4 & - & - & - & - & - & - & - & " \\
\hline & & 5 & - & - & - & - & - & - & - & 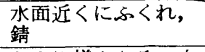 \\
\hline & & 6 & - & - & - & - & - & - & - & $\begin{array}{l}\text { しみ模様となる, 白 } \\
\text { 濁 }\end{array}$ \\
\hline \multirow{2}{*}{ 油性 } & \multirow{2}{*}{ 要 酸 化 鉊 } & 7 & - & - & $-\cdot 1$ & - & - & - & - & $\begin{array}{l}\text { 10日ふくくれ，軟化， } \\
\text { しわ,はがれ }\end{array}$ \\
\hline & & 8 & - & - & -1 & - & - & - & - & $\begin{array}{l}2 \text { 時間全面ふくはれ, } \\
\text { 軟化, 10日かれ }\end{array}$ \\
\hline \multirow{3}{*}{$100 \% フ ェ ノ ー ル$} & 垔 鉊 末 & 9 & - & - & - & - & - & - & - & $\begin{array}{l}2 \text { 時間大ふくく、錆 } \\
\text { が }\end{array}$ \\
\hline & シアナミド鉊 & 10 & 一 & - & - & - & - & - & - & $\begin{array}{l}2 \text { 時間大ふくくれ，10 } \\
\text { 日, はがれ }\end{array}$ \\
\hline & $ア ル ミ$ 粉 & 11 & - & - & - & - & - & 色 & 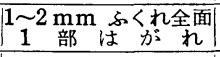 & $\begin{array}{l}\text { 1時間大小ふくれ， } \\
\text { 抱水 }\end{array}$ \\
\hline \multirow{4}{*}{ 塩化 $ヒ ゙=ル$} & \multirow{4}{*}{ 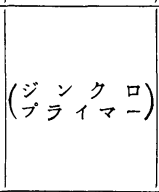 } & 12 & - & - & - & - & - & - & - & $\begin{array}{l}2 \text { 時䦩大ふくれ，10 } \\
\text { 日全ふくれ }\end{array}$ \\
\hline & & 13 & - & - & - & - & - & 良 & 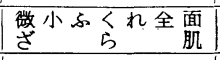 & $\begin{array}{l}\text { 4日ざらつき, 微小 } \\
\text { ふく軟化 }\end{array}$ \\
\hline & & 14 & - & - & - & - & - & 一 & - & $\begin{array}{l}\text { 7日ざらつき,ふく } \\
\text { れ, 25日大ぶれ }\end{array}$ \\
\hline & & 15 & - & - & - & - & - & - & - & $\begin{array}{l}\text { 2日大ふくれ, 上塗 } \\
\text { りはがれ }\end{array}$ \\
\hline 塩化ピニリデン & 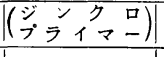 & 16 & - & - & - & - & - & - & - & $\begin{array}{l}\text { 1時間大ふくくれ，20 } \\
\text { 日文くれ、はがれ }\end{array}$ \\
\hline \multirow{3}{*}{ エポキシ } & \multirow{3}{*}{ 酸 化 鉄 } & 17 & - & - & - & - & - & - & - & $\begin{array}{l}\text { 10日ふくれ，20日亀 } \\
\text { 裂、はがれ }\end{array}$ \\
\hline & & 18 & - & - & - & - & - & - & - & 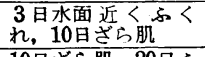 \\
\hline & & 19 & - & - & - & - & - & - & - & $\begin{array}{l}\text { 10日ざら肌, 20日ふ } \\
\text { くれ, はがれ }\end{array}$ \\
\hline $\begin{array}{r}\text { ポリエステル } \\
\text { 十エポキシ } \\
\end{array}$ & 酸 化 鉄 & 20 & - & - & - & - & - & - & - & \\
\hline サ ラ ン & - & 21 & - & - & - & - & - & 良 & 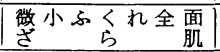 & $\begin{array}{l}\text { 10日ざら肌，20日大 } \\
\text { ふくくれ }\end{array}$ \\
\hline \multirow{2}{*}{ ポリウレタン } & \multirow{2}{*}{ 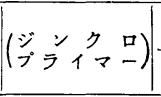 } & 22 & - & - & - & - & - & - & - & $\begin{array}{l}2 \text { 時間小ふくくれ， } 5 \\
\text { 沓くれ多 }\end{array}$ \\
\hline & & 23 & - & - & - & - & - & - & - & $\begin{array}{l}2 \text { 晆闃小らくくれ，5 } \\
\text { 日半面ばれ }\end{array}$ \\
\hline \multirow{2}{*}{$>\quad \bar{V}$} & - & 24 & - & - & - & - & - & - & 一 & $\begin{array}{l}2 \text { 時閪小らくれ、 } \\
\text { 日全面はがれ }\end{array}$ \\
\hline & - & 25 & - & - & - & - & - & - & - & 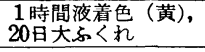 \\
\hline \multirow{3}{*}{$=-n g-n$} & \multirow{2}{*}{ 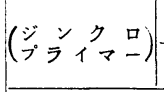 } & 26 & - & - & - & - & - & - & - & 10日ふくれ，軟化 \\
\hline & & 27 & - & - & - & 一 & - & - & - & 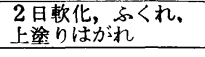 \\
\hline & |(エポキシ変性)| & 28 & - & - & - & - & - & - & - & - \\
\hline & - & 29 & - & - & - & - & -1 & - & - & 10日軟化, 亀裂, 錆 \\
\hline シンクリッチ & 垔 鉊 末 & 30 & 4 & やや良 & 0.10 & 灰 & $\begin{array}{l}\text { 部分的 } \rightarrow \\
\text { s }<れ\end{array}$ & 14 日 浸 清 & 小心くれ全面 & - \\
\hline カ $=-$ & - & 31 & 2 & （䚁付） & 6 & 褐 & 合 格 & 微小ふくれ全面 & 大小ふくれ全面 & $\begin{array}{l}2 \text { 昌ふくくれ，4日 } \\
\text { 大はかれ }\end{array}$ \\
\hline & - & 32 & 2 & 良 & 6 & 白 & $"$ & 一部小ふくれ & 週辺に小ふくれ & $\begin{array}{l}3 \text { 時間小らくくれ、2 } \\
\text { 日大はかれ }\end{array}$ \\
\hline & - & 33 & 2 & （焼付） & 5 & " & " & 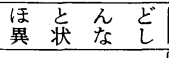 & $\begin{array}{l}\text { 小忍くしれ全面 } \\
\text { 1部大ふくれ、はかれ }\end{array}$ & 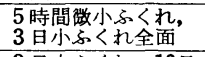 \\
\hline エポ & - & 34 & 2 & 良 & 8 & " & "l & - & - & $\begin{array}{l}\text { 3日小而くれ，10日 } \\
\text { 大示くれ }\end{array}$ \\
\hline & - & 35 & 2 & " & 9 & " & $"$ & - & - & $\begin{array}{l}\text { 3日小而くれ，10日 } \\
\text { 大糸くれ }\end{array}$ \\
\hline & 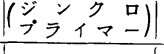 & 36 & 2 & "I & 9 & " & " & ほとん & ぞ異状なし & " \\
\hline × & $\mid-1$ & 37 & 2 & "I & 8 & " & " & - & - & " \\
\hline
\end{tabular}


系 1 点のみ錆発生), 刽離は認められず, 更に電気化学 的測定結果とあわせて考察すると, 塗膜のふくれは上塗 りの部分の吸水によって起こったもので，図 3 のごと

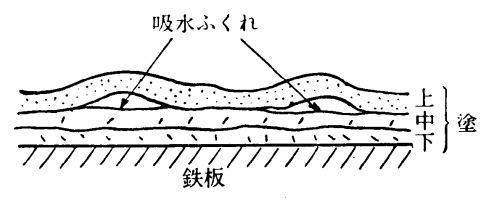

図 3 塗膜のふくれ模型

く中，下塗りはまだ鉄素地に密着しているものと思われ る。

このような観点からすると塗膜の全抵抗は, 各重ね狳 り塗膜が密着していた初期に比べて余り減少していない わけである。ここで吸水された内部の純水注，その比抵 抗がかなり大きいことも一因となっているものと考えら れる。

以上の程度のふくれでは, 塗膜はまだ十分防錆効果が 保たれているが，このふくれが破れ，更に中，下塗りに ふくれを生ずると, やがては発錆を免れないものと思わ れる。そこで, 本試験継続 1 力年後の電気化学的測定值 からは劣化の程度を判定し得ないが, 肉眼観察でふくれ を認めた塗膜を一応劣化したものとすると，コールター ルエナメルが最も良く, 次いで塩化ビニル系, エポキシ 系塗料が比較的耐久性が良いものといえる。

\section{7) 温水器内部用塗料試験}

約 40 種の防食塗料の記述のごとき試験片を用い, 次 のごとく沸騰水中および温湯中での浸漬試験を行ない比 較検討した。結果を総括すれば表 2 のごとくであって，

(1) 熱湯浸漬試験

塗装試験片を $100^{\circ} \mathrm{C}$ の微沸騰水中に浸漬し試験を行 なった結果, 数時間〜数日間でふくれ, 軟化, 亀裂等を 生じ, 塗膜の健全なものはなかった。ジンクリッチペイ ントは Zn の溶出が多く, 次第に隇少はするが, 長期の 試験では大部分のものがふくれ，点錆を生じた。

(2) 温湯浸漬試験

上記の熱湯浸漬試験で比較的長時間の耐久性のあるる のの中から塗料系別に数点選び, 温湯に長期浸漬試験を 行なった。温度は $60^{\circ} \mathrm{C}$ に保ち毎日 8 時間加温し, 50
日間継続した（温水器内の水温は大体 $40 \sim 60^{\circ} \mathrm{C}$ であ る)。

試験の結果では, エポキシ系焼付塗料, 塭化ビ ニル 系，サラン系塗料が，多少はふくれを生ずるが，比較的 実用性があるものと思われる。また溶出量の少ないジン クリッチペイントもかなり耐温水性があるように思われ る。

\section{4. 総括}

鋼製水槽および温水器の内面防食用塗料に関する研究 は比較的少ない。この点に鑑み，国鉄客車用床下水槽お よび温水器の内面防食塗装の目的で前者に対しては市販 の防食塗料約 30 種余りの塗装試験片について, 塗料の 作業性, 膜厚, 密着性, 耐塩水試験更に通電劣化促進試 験および蒸留水長期浸漬試験をも行ない, 後者に対して は約 40 種の塗料について熱湯, 温湯への浸漬試験を行 ない, それらの性能, 塗膜の異状を検討し, 耐久性良好 な淮料選定に供しようとした。

結果として水槽内面用としてコールタールエナメルが 良好であり，この内でも溶液型で良質のものが実用性が 高いと思われる。他の塗料ではふくれを生ずるものが多 いが, この内でも塩化ビニル系, エポキシ系塗料は比較 的良好であった。

次に温水器内面用のものでは十分満足し得るものは選 び出し得なかったが，エポキシ系焼付塗料が比較的良 く, サラン系, 塩化ビニル系のものがこれに次いだ。な おジンクリッチペイントで溶出量の少ないものもかなり 良好と思われる。

なお，塗膜の溶出によるタンク内の水の変質はその電 気抵抗変化の測定から見ると問題は少なく（フラン系塗 料を除き)，使用上の問題はないように思われた。ただ しジンクリッチペイントの内には亜鉛の溶出するものが あり，水の白濁する場合が認められた。

(昭和 37 年 5 月 17 日受理)

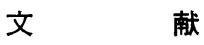

1) J.D. Keane \& J. Bigos: J. Am. Water Works Assoc, 52, No. 5, $623(1960)$

2) D. W. Christofferson: ibid., 53, No. 6, 725 (1961)

3) H. Moroson: Corrosion, 17, No. 5, 28 (1961)

4) 吉沢, 日根：材料試験, 8, No. 64, 2 (1959)

5) 网本, 諸住. 山科: 工化誌, 61, 291 (1958)
(10 頁から続く)

$\tan \delta$ 值から予想するように, 防食効果の予測を蒸留水 の場合にも同一に当てはめてよいとは限らないことがわ かった。

終りに, 本実験に当り, 電気化学的測定その他に援助 を頂いた佐藤靖, 神岡正男, 実験に協力された田辺俊勝
の諸氏に深謝します。

（昭和 37 年 5 月 22 日受理）

\section{文}

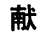

1）後藤田, 関口：防蝕技術, 11, No. 8, $337(1962)$

2) 岡本, 諸住, 山科: 工業化学雑誌, 61, 291 (1958)

3）佐藤, 神岡：鉄道技術研究報告 第 42 号 (1958) 